\title{
Isotopic evidence for mobility at large- scale human aggregations in Copper Age Iberia: the mega-site of Marroquíes
}

Marta Díaz-Zorita Bonilla ${ }^{1,2,3,}$, Jess Beck ${ }^{4}$, Hervé Bocherens ${ }^{2,3,5}$ \& Pedro Díaz-del-Río ${ }^{6}$

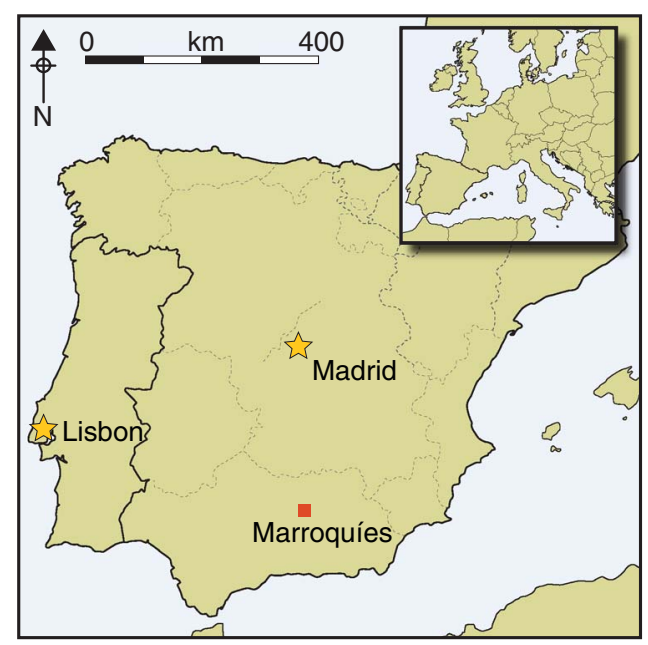

Settlements incorporating large-scale buman aggregations are a well-documented but poorly understood phenomenon across late prehistoric Europe. The authors' research examines the origins and trajectory of such aggregations through isotope analysis of human skeletal remains from the mega-site of Marroquies in Jaén, Spain. The results indicate that eight per cent of 115 sampled individuals are of non-local origin. These individuals received mortuary treatments indistinguishable from those of locals, suggesting their incorporation into pre-existing social networks in both life and death. This research contributes to our understanding of the extent and patterning of human mobility, which underlies the emergence of late prehistoric mega-sites in Europe.

Keywords: Iberia, Marroquíes, Copper Age, mobility, isotope analysis

1 Institut für Ur- und Frühgeschichte und Archäologie des Mittelalters, Eberhardt Karls Universität, Schloß Hohentübingen, 72070 Tübingen, Germany

2 Institut für Geowissenschaften, Eberhardt Karls University, Hölderlinstrasse, 12, 72074 Tübingen, Germany

3 SFB 1070 Ressourcenkulturen, Gartenstrasse 29, 72074 Tübingen, Germany

4 McDonald Institute for Archaeological Research, Downing Street, Cambridge CB2 3ER, UK

5 Senckenberg Centre for Human Evolution and Palaeoenvironment, Sigwartstrasse 10, 72076 Tübingen, Germany

6 Instituto de Historia, CSIC, C/Albasanz 26-28, 28037, Madrid, Spain

* Author for correspondence (Email: marta.diaz-zorita-bonilla@uni-tuebingen.de)

(C) Antiquity Publications Ltd, 2018 This is an Open Access article, distributed under the terms of the Creative Commons Attribution-NonCommercial-NoDerivatives licence (http://creativecommons.org/licenses/by-ncnd/ $4.0 /$ ), which permits non-commercial re-use, distribution and reproduction in any medium, provided the original work is unaltered and is properly cited. The written permission of Cambridge University Press must be obtained for commercial re-use or in order to create a derivative work.

ANTIQUiTy 92364 (2018): 991-1007

https://doi.org/10.15184/aqy.2018.33 


\section{Introduction}

One of the most intriguing questions in the comparative study of early complex societies relates to the circumstances that led to the emergence of large-scale human aggregations (Birch 2013). In later prehistoric Europe, such aggregations flourished on the southern Iberian Peninsula around 3000 cal BC, only half a millennium after the demise of its eastern Trypillian counterparts (with Trypillia being the other outstanding process of human aggregations in mega-sites known for late prehistoric Europe) (Müller et al. 2016). Characterised by massive communal labour investments in building fortifications and ditches, Iberian mega-sites persisted for several centuries. All were subject, however, to radical reorganisation or collapse by the late third millennium BC (Balsera et al. 2015: 149).

The extent to which these aggregations resulted from local, regional or extra-regional human mobility is an issue of critical importance for understanding the complexity of megasites and their place in regional networks (e.g. Nocete et al. 2010; Díaz-del-Río 2013; DíazZorita Bonilla 2017; García Sanjuán et al. 2018). Fortunately, the extensive mortuary component of many Iberian Copper Age mega-sites allows for the study of human mobility through the direct analysis of human skeletal remains.

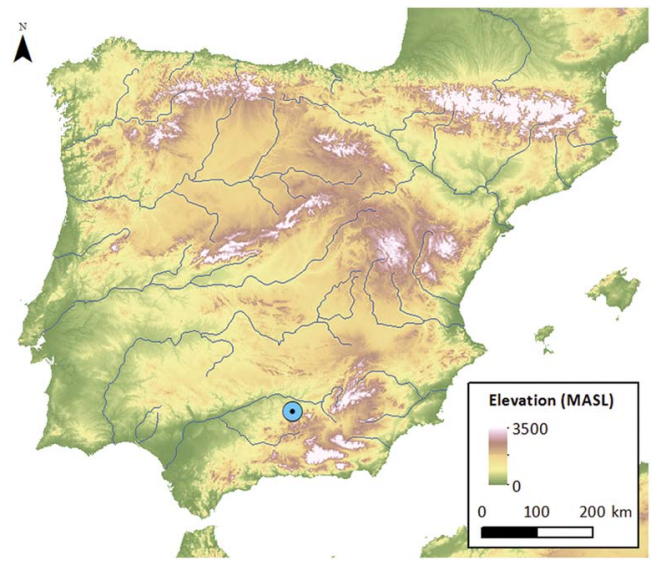

Figure 1. Location of Marroquies (Jaén, Spain). Base cartography: SRTM $90 \mathrm{~m}$ digital elevation data (Jarvis et al. 2008). Mapa Digital de Andalucia 1:100.000 Junta de Andalucia. Courtesy of Antonio Uriarte, Instituto de Historia, CSIC. understanding population history at the site of Marroquíes, and to the comparative study of large-scale aggregation processes in Iberia and beyond.

\section{The mega-site of Marroquíes}

At 113ha, the ditched enclosure settlement of Marroquíes is the second largest mega-site known in Copper Age Iberia (Zafra et al. 1999, 2003), after Valencina-Castilleja (García Sanjuán et al. 2018). The site is located in the foothills of the Sierra de Jaén, in an ecotone between the low hills of the campina to the north and the steeper mountain range of the (C) Antiquity Publications Ltd, 2018 


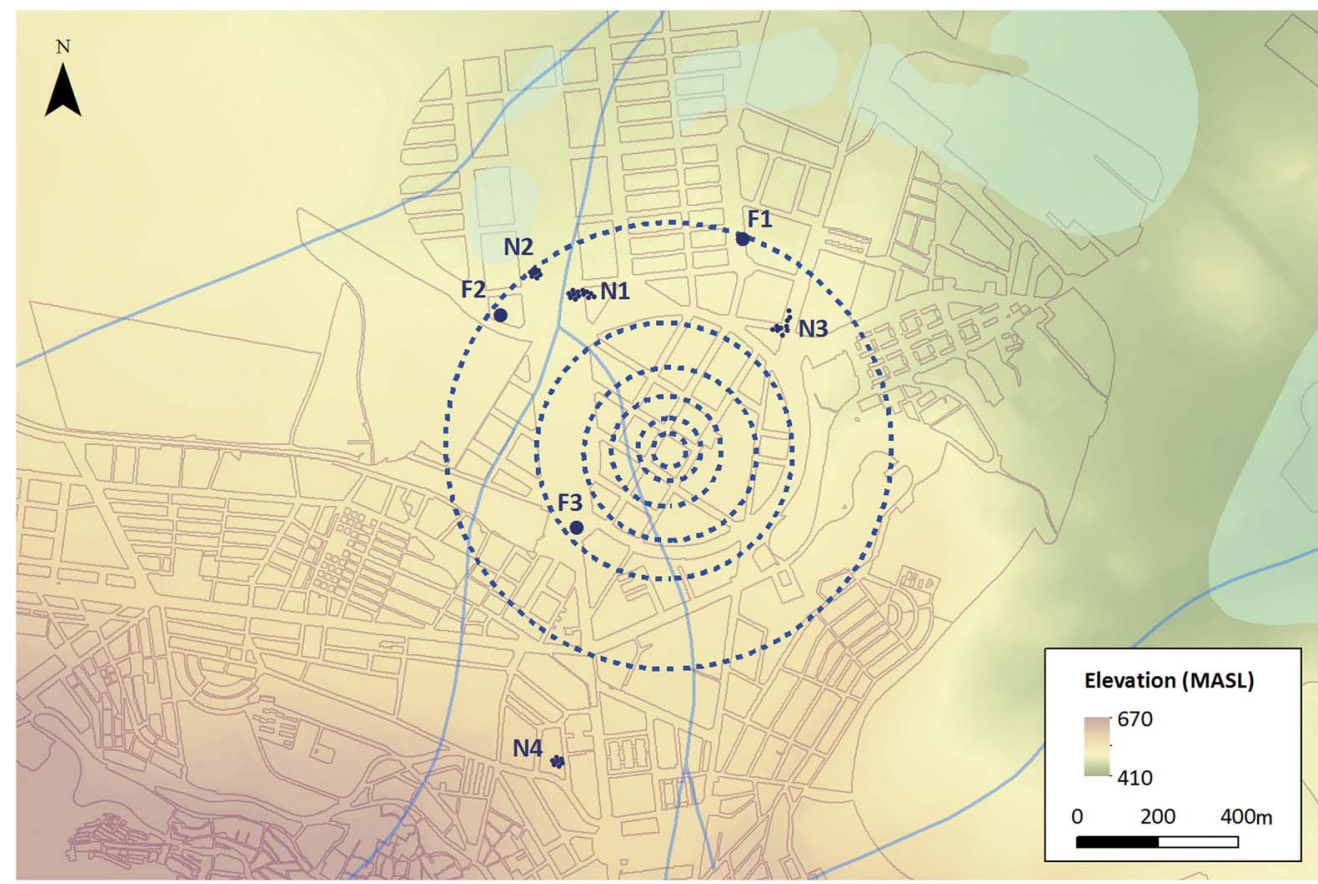

Figure 2. Schematic map of Marroquies with the distribution of mortuary areas (necropolises 1-4; F1-3: Fosa comun or 'common grave') and enclosures (Narciso Zafra pers. comm.). Base cartography: CartoCiudad and Modelo Digital del Terreno MDT05 provided by (C) Instituto Geográfico Nacional. Courtesy of Antonio Uriarte, Instituto de Historia, CSIC.

Sierra Mágina to the south (Figure 1). Geologically, Marroquíes is situated in the northern External Zone of the Baetic System, where the bedrock comprises Jurassic limestone and Cretaceous loam.

Discovered in 1957 during construction work (Espantaleón 1957, 1960), the full extent of the Marroquíes site was not appreciated until the northward expansion of the modern city in the 1990s precipitated a wave of over 270 archaeological excavations (Zafra et al. 2003). These investigations uncovered a series of six concentric ditches (ranging from $6-10 \mathrm{~m}$ in width and $2-5 \mathrm{~m}$ in depth), portions of an adobe wall accompanying the fifth ditch, and extensive evidence for domestic architecture and mortuary features (Figure 2).

Ninety-five radiocarbon dates from the prehistoric occupation contexts suggest an initial foundation of the two inner enclosures by $2800-2450 \mathrm{cal} \mathrm{BC}$ (covering $1.1 \mathrm{ha}$ ), a peak in activity c. $2450 \mathrm{cal} \mathrm{BC}$ that triggered sequential construction of the remaining enclosures (covering 113ha), and a steep decline in human activity by 2100 cal BC (Cámara et al. 2012a \& b; Aranda Jiménez et al. 2016; Beck 2016). During the most active phase of the site, multiple huts with circular trench foundations were clustered in dispersed 'neighbourhoods' (Zafra et al. 2003), with no clear evidence for community-level organisation of households. The density of such huts at one of the most thoroughly investigated areas of excavation allows for an initial estimation of population size (Junta de Andalucía 2010). Taking into account the $677 \mathrm{~m}^{2}$ of hut surface per hectare and one person per $6.9 \mathrm{~m}^{2}$ (Porčić 2012) of the $34 \mathrm{ha}$ 
within ditch 4, we estimate that, at its peak, Marroquíes may have had a mean population of 3300 inhabitants.

This local history of labour investment is paralleled by regional settlement dynamics. Results of the Upper Guadalquivir Valley Survey Project show a decrease in the number of settlements throughout the Guadalbullón River Valley by 2500 cal BC (Nocete 1994). Díazdel-Río (2004) interprets this as a direct consequence of the rise of the Marroquíes mega-site. The survey also identified a later increase in the number of sites in the river valley by $2200 \mathrm{cal}$ $\mathrm{BC}$ - a pattern that probably resulted from the subsequent steep decline in activity at Marroquíes. The exponential intensification in labour investment by $2450 \mathrm{cal}$ BC suggests that the location and population of Marroquíes acted as an incentive for newcomers, whose incorporation into the settlement would have required new forms of integrative social mechanisms.

Since 2013, the Marroquíes Bioarchaeological Project has combined bioarchaeology, mortuary archaeology, isotopic analyses of diet $\left(\delta^{13} \mathrm{C}, \delta^{15} \mathrm{~N}\right)$ and mobility $\left({ }^{87} \mathrm{Sr} /{ }^{86} \mathrm{Sr}, \delta^{18} \mathrm{O}\right)$, and radiocarbon dating to investigate social organisation, patterns of aggregation and funerary activity at the site. Here, we present carbon $\left(\delta^{13} \mathrm{C}_{\mathrm{ap}}\right)$, strontium $\left({ }^{87} \mathrm{Sr} /{ }^{86} \mathrm{Sr}\right)$ and oxygen $\left(\delta^{18} \mathrm{O}\right)$ isotope analyses of human skeletal remains from 115 individuals interred in three different mortuary areas at Marroquíes. Samples were selected taking into account spatial distribution, minimum number of individuals (MNI) estimates and chronological variability in mortuary practices (Beck 2016).

\section{The mortuary record}

Seven mortuary areas are identified at Marroquíes (Figure 2). Other than the artificial caves of the Marroquíes Altos necropolis, these locations are characterised by clusters of circular subterranean structures or amorphously defined pits excavated into bedrock. The burials encompass different mortuary treatments, including primary burials, secondary burials and commingled interments. Grave goods include complete animal burials and occasional ceramics, shell, worked bone implements and metal objects. MNI estimates range from five (at F1) to over 200 (at necropolis 4 (N4)). Most of the AMS radiocarbon dates from two previously analysed mortuary areas fall in the mid to late third millennium BC (c. 25002000 BC) (Sánchez et al. 2005; Cámara et al. 2012a \& b). Necropolises 1 (N1), 2 (N2) and 4 (N4) were analysed most recently (Beck 2015, 2016, 2017).

N1 was excavated in 1998-1999 and contained at least 42 individuals (Serrano et al. 2000) (Figure 3). Its mortuary structures included type 1 tombs, comprising a series of bellshaped features $6 \mathrm{~m}$ in diameter and $1.5-2 \mathrm{~m}$ in depth. These were dug into the marl, with multiple burials clustered in a circular arrangement around a central tomb containing a single probable male burial. $\mathrm{N} 1$ also contained smaller pits (type 2) $2-3 \mathrm{~m}$ in diameter and $0.5 \mathrm{~m}$ in depth, which were also dug into the marl. Grave goods were limited or absent, although type 1 tombs contained burials of whole animals. All type 1 tombs experienced domestic or utilitarian re-use during the Late Copper Age or Early Bronze Age. AMS dates for nine human samples suggest that these mortuary structures were in use between 2690 and 2300 cal BC (Beck 2016) (online supplementary material (OSM) Table S1; Figure 4).

(C) Antiquity Publications Ltd, 2018 

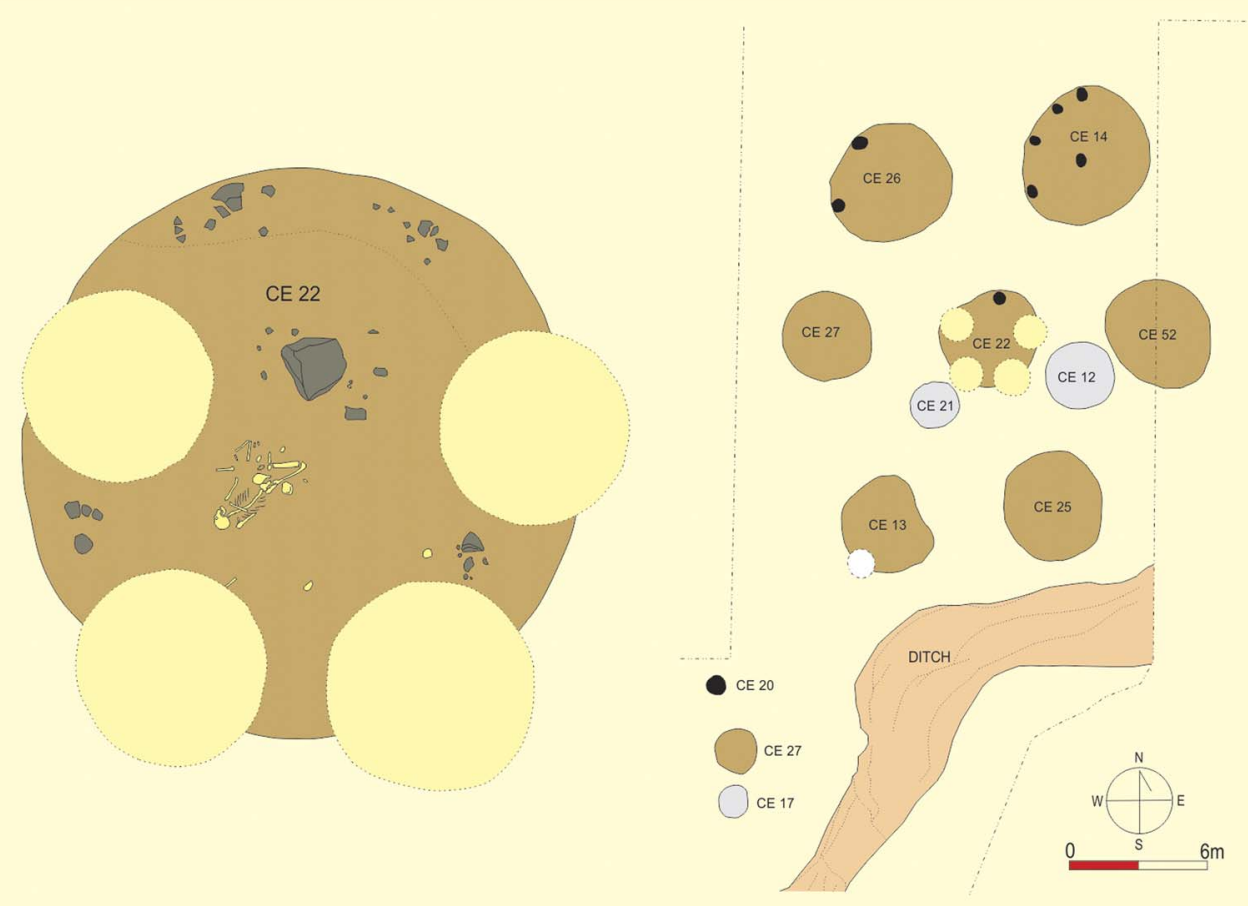

Figure 3. Necropolis 1. Map of mortuary structures and detail of central burial structure CE22. Black dots represent hearths (modified from site map by José Luis Serrano Peña).

Excavated in 2006, N2 contained at least 33 individuals. It comprised seven mortuary structures containing disarticulated human remains distributed along the internal edge of ditch 5, and a cranium recovered from within the ditch (Pérez 2005). Here, mortuary structures included: 1) oval or irregular structures with burials in shallow $0.3-0.4 \mathrm{~m}$-deep graves, with dimensions ranging from $0.9-1.6 \mathrm{~m}$ in length and $1-2.7 \mathrm{~m}$ in width; 2) structures of oval or irregular shape (100mm in depth, $3-5 \mathrm{~m}$ in length and $2-5 \mathrm{~m}$ in width), with burials interred directly on the natural clay substrate; and 3) circular structures $1.7 \mathrm{~m}$ in diameter, with stone covers and burials interred directly on the clay substrate. N2 also contained large and often well-preserved ceramics, bone awls/hairpins and one sword blade with rivets. AMS dates from human mandibles show two distinct periods of use: a phase of Late Copper Age mortuary activity (2580-2340 cal BC), followed by an Early Bronze Age phase (2180-1960 cal BC) (Beck 2016).

N4 was discovered during construction work in 1957 and is known as Marroquíes Altos (Espantaleón 1957). It is the only mortuary area situated outside of the enclosures (Figure 1), located about $500 \mathrm{~m}$ south on the slope of the hill of Santa Catalina. At least seven artificial caves have been discovered in this area, distributed in a complex that covers approximately 0.1ha (Espantaleón 1957, 1960; Lucas 1968) (Figure 1). All but one cave contained human burials and associated artefacts suggesting a Late Copper/Early Bronze Age chronology. Two burial caves (tombs I and II) were partially excavated in the 1950s (Espantaleón 1957). Due to further construction at the site in 2001, these tombs were re-excavated (Manzano \&

(C) Antiquity Publications Ltd, 2018 


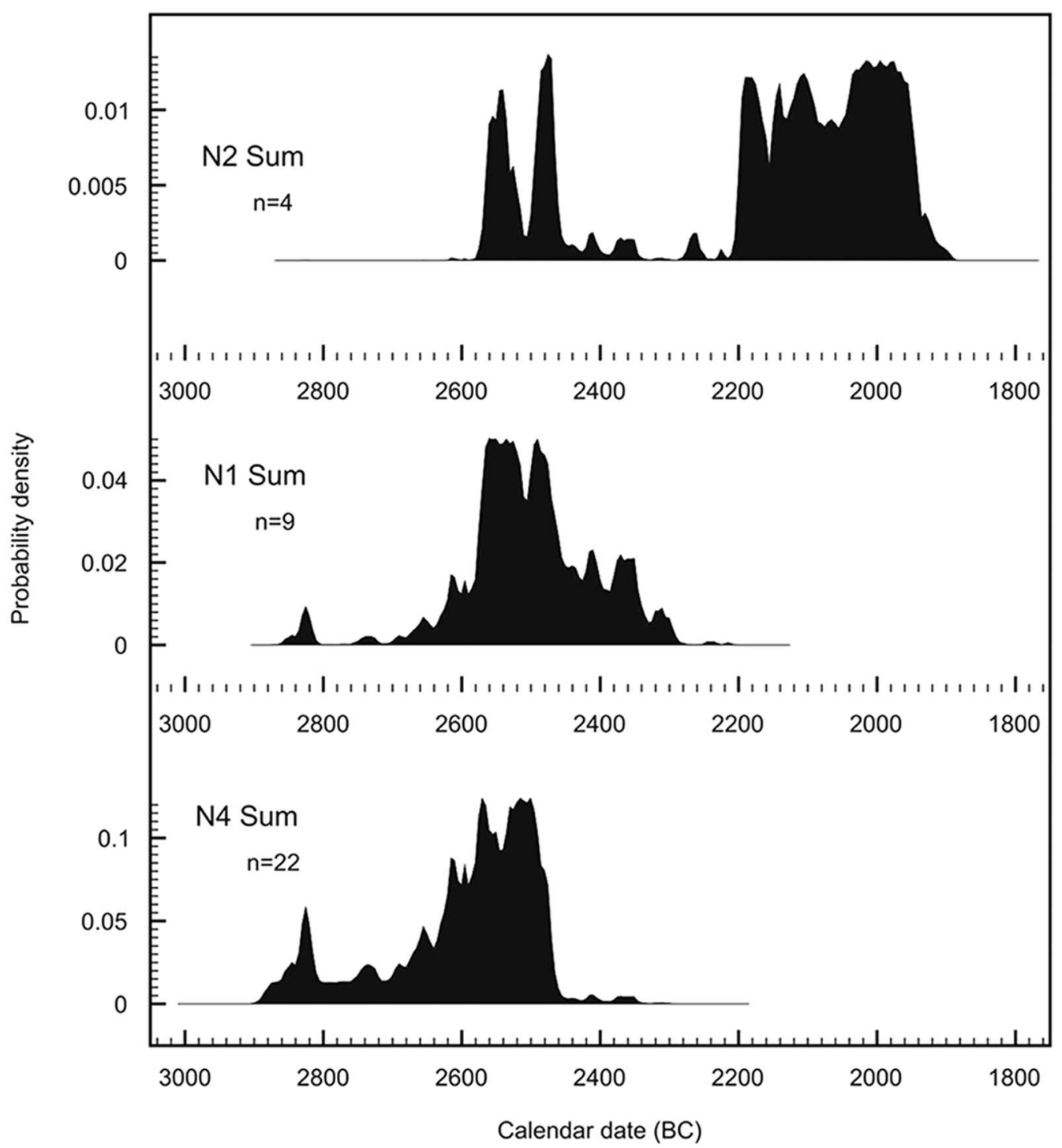

Figure 4. AMS radiocarbon dates from necropolises 1, 2 and 4.

Martínez 2001). Archaeologists discovered the prehistoric entryways and antechambers for tombs I and II-important components of the site left undisturbed by the earlier excavations. They also discovered a new undisturbed tomb (tomb III), the only artificial cave excavated entirely in situ (Figure 5). The three mortuary caves are oriented north-east to south-west and share a similar plan, with a vertical access shaft, antechamber and chamber. Fragmentary and commingled human remains, sometimes mixed with broken artefacts, completely fill the caves.

Our project has analysed human remains from all three caves (Beck 2016). Tombs I and II were combined in analysis due to the potential admixture of human remains over the course of multiple excavations, and contained at least 165 individuals. Tomb III contained at least (C) Antiquity Publications Ltd, 2018 


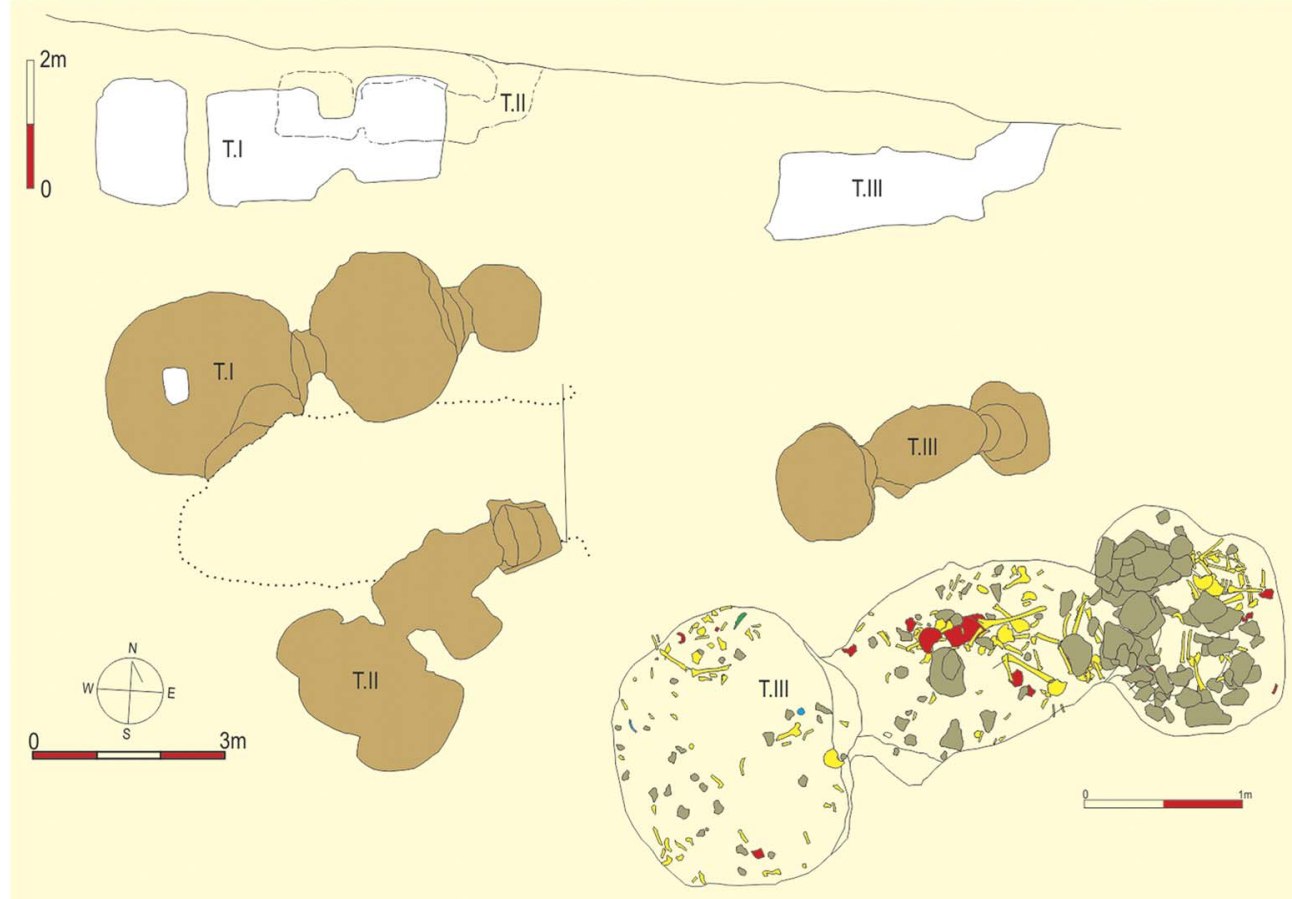

Figure 5. Necropolis 4 (Marroquies Altos). Plan and section of the three analysed artificial caves and detail of the distribution of human remains in tomb III (modified from site maps by Ana Manzano Castillo and José Luis Martinez Ocaña).

40 individuals. AMS dates from individuals interred in tombs I and III suggest that both caves were used during the same period, with mortuary activity beginning by $c .2720 \mathrm{BC}$ and ending by c. $2460 \mathrm{cal} \mathrm{BC} \mathrm{(Beck} \mathrm{2016).} \mathrm{This} \mathrm{chronology} \mathrm{makes} \mathrm{the} \mathrm{first} \mathrm{burials} \mathrm{at} \mathrm{N4}$ contemporaneous with the construction and use of the two inner enclosures at Marroquíes.

\section{Methods and dataset}

Bioarchaeological analysis of the newly analysed human remains produced an MNI estimate of 280 (201 adults, 79 subadults), while estimations of sex (OSM Appendix 2) in adults yielded 47 females and 31 males (Beck 2016). One hundred and fifteen human tooth samples were collected from mortuary areas N1, N2 and N4, as well as two lagomorph (e.g. rabbit) teeth, one lagomorph tibia and one ovicaprid tibia from N4. The human sample represents respectively 52,34 and 40 per cent of the MNI per burial area. To prevent the double-counting of individuals, sub-adult samples were selected based on the presence of the $\mathrm{Rdm}_{2}$ (lower right deciduous second molar), and adult samples were selected based on the presence of the $\mathrm{RM}_{2}$ (lower right permanent second molar). Approximately $12 \mathrm{mg}$ of enamel was extracted from each tooth. The human isotopic sample reflects the overall MNI distribution, with comparable proportionality of age categories, sexes and mortuary areas. Samples were extracted

(C) Antiquity Publications Ltd, 2018 
and processed at the Department of Geosciences (University of Tübingen) (see the OSM for specific laboratory methodology). Due to the dearth of faunal tooth enamel, bone samples from lagomorphs and ovicaprids were analysed to assess the local range for ${ }^{87} \mathrm{Sr} /{ }^{86} \mathrm{Sr}$.

\section{Results}

All 115 human tooth samples collected from N1, N2 and N4 were suitable for strontium $\left({ }^{87} \mathrm{Sr} /{ }^{86} \mathrm{Sr}\right.$ ) isotope analysis (Table S2). Price et al. (2001) recommend the use of a $2 \sigma$ confidence interval around the mean to establish a local human range. As the N1, N2 and N4 human strontium isotope ratios departed significantly from a normal distribution (ShapiroWilks W test for non-normality $=0.62185$, p-value $=1.742 \mathrm{e}-15)$, however, both a $1 \sigma$ $(0.70761-0.70934)$ and a $2 \sigma(0.70675-0.71020)$ local range were employed to avoid underestimating the number of non-local individuals at Marroquíes. Nine non-local individuals were identified at $1 \sigma$, and six non-local individuals were identified at $2 \sigma$ (Figure 6). Here, we follow a more conservative approach using the $2 \sigma$ boundary, treating only six individuals (samples 11, 12, 20, 51, 78 and 80) as non-local; we are aware, however, that three additional individuals show values distinct from the local range at $1 \sigma(68.2 \%$ confidence). These individuals may also have been of non-local origin, but further data are needed to assess their status more accurately.

These 119 human and faunal samples were also analysed for oxygen $\left(\delta^{18} \mathrm{O}\right)$ and carbon $\left(\delta^{13} \mathrm{C}_{\mathrm{ap}}\right)$ of the carbonate fraction of enamel and bone bioapatite (OSM Appendix $1 \&$ Table S3; Figure 7). Due to the fractionation that occurs when humans consume water (Chenery et al. 2012), $\delta^{18} \mathrm{O}$ values were converted to reflect drinking water using the Daux et al. (2008) formulae. Results for all humans showed an average $\delta^{18} \mathrm{O}_{\mathrm{dw}}$ value of $-9.47 \%$ ranging from $-13.72 \%$ to $-6.72 \%$, with sub-adult values ranging from $-10.65 \%$ o to $-9.11 \%$ o. Human $\delta^{18} \mathrm{O}_{\mathrm{dw}}$ values had a range of $11 \%$, while faunal values had a range of $-5 \%$. Values of drinking water $\delta^{18} \mathrm{O}$ calculated from human $\delta^{18} \mathrm{O}$ were compared to modern precipitation values to establish a range for local water sources using nearby locations with similar environmental conditions (available at: http://waterisotopes.org; WaterIsotopes

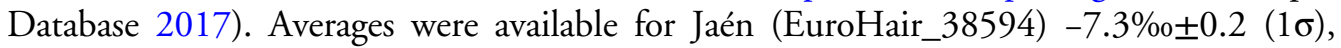
Montejícar (EuroHair_38594) $-8.0 \%$ \pm 0.2 , Granada (EuroHair_38595) -9.36\% \pm 0.2 and Guadix (EuroHair_38596) -8.73\%o土0.2 (Bowen \& Revenaugh 2003; Bowen et al. 2005). Bowen and Revenaugh (2003) suggest that local $\delta^{18} \mathrm{O}$ values for the site area range from $-7.5 \%$ o to $-11.4 \%$, which coincides with the human $\delta^{18} \mathrm{O}_{\mathrm{dw}}$ average $(-9.47 \%$ ) . As a result, we established a local $\delta^{18} \mathrm{O}$ value range of $-10.91 \%$ o to $-8.04 \%$ o. Thirty-four values for human samples from all burial sites $(\mathrm{N} 1=9 ; \mathrm{N} 2=2 ; \mathrm{N} 4=24)$ fall out of this range. Five of them are also outliers according to the ${ }^{87} \mathrm{Sr} /{ }^{86} \mathrm{Sr}$ results $(\mathrm{N} 1=3 ; \mathrm{N} 4=2)$ (Figure 6).

The human sample $(n=115)$ showed a $\delta^{13} \mathrm{C}_{\mathrm{ap}}$ average of $-12.30 \% \mathrm{o} \pm 0.5(1 \sigma)$, while fauna $(n=4)$ averaged $-12.12 \% \pm \pm 1.7(1 \sigma)$. Values from human enamel samples ranged from $-13.68 \%$ o to $-11.14 \%$. Faunal remains for enamel ranged from $-14.06 \%$ to $-11.26 \%$ and from $-13.04 \%$ o to $-10.15 \%$ o for bone apatite. There is a difference of $4 \%$ o among humans and of $-4 \%$ among faunal remains. The human sample mean of $-12.30 \%$ is consistent with the consumption of $\mathrm{C}_{3}$ plants or animal products from $\mathrm{C}_{3}$-plant foodwebs (van der Merwe 1982).

(C) Antiquity Publications Ltd, 2018 


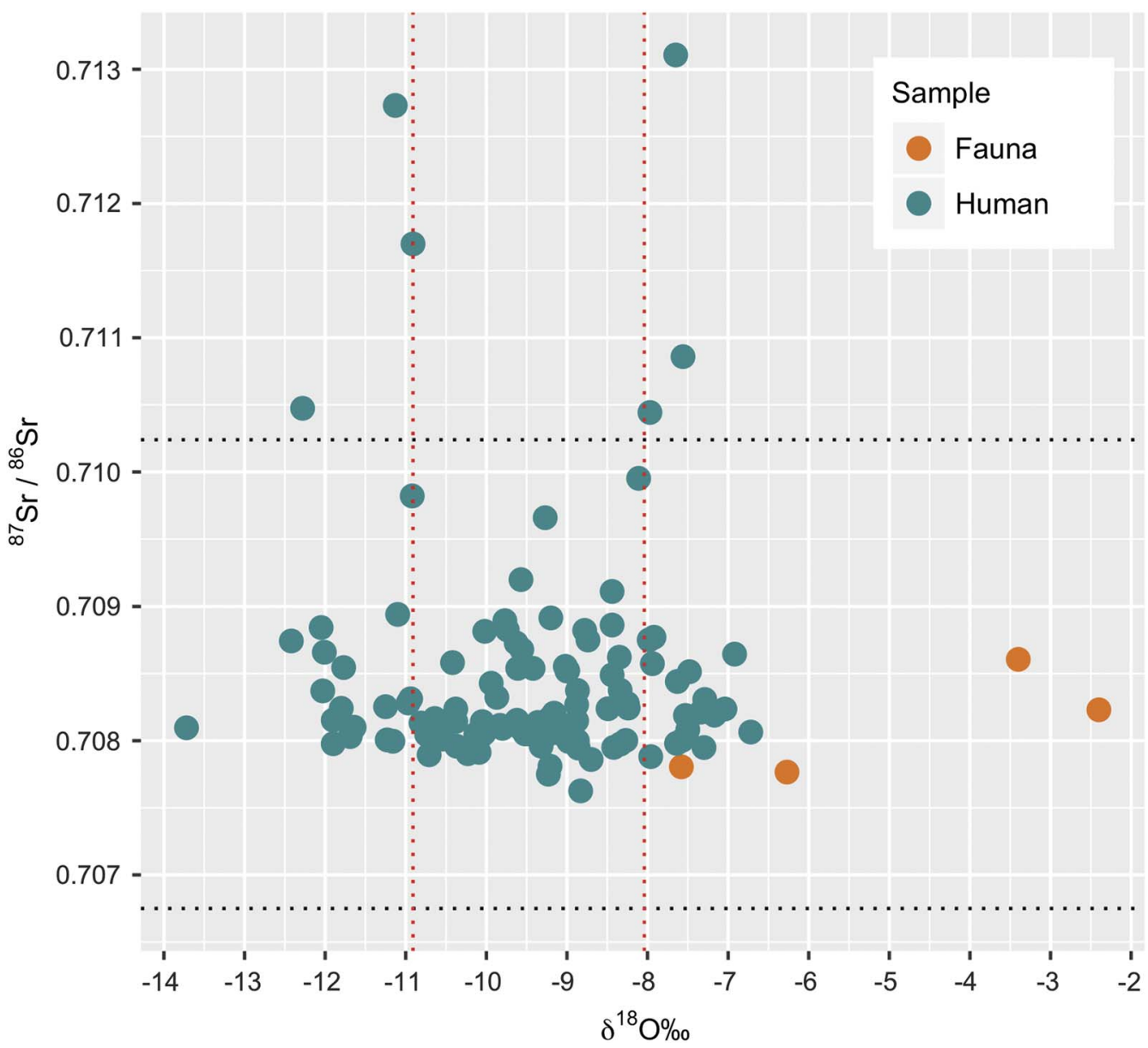

Figure $6{ }^{87} \mathrm{Sr}{ }^{86} \mathrm{Sr}$ and $\delta^{18} \mathrm{O}_{d w}$ values for human and faunal samples from Marroquies. Black dotted lines represent $\pm 2 \sigma\left(95.4 \%\right.$ confidence) from the human mean for ${ }^{87} \mathrm{Sr}{ }^{\beta 6} \mathrm{~S} r$; red dotted lines represent $\pm 1 \sigma(68.2 \%$ confidence) from the human mean for $\delta^{18} O_{d w}$.

\section{Discussion}

The northern geological limits of this region are the Subbetic olistostrome unit, the Neogene and Quaternary Basin of the Guadalquivir, and the Iberian Massif. Southwards, the Internal Zone of the Baetic System includes metasedimentary Mesozoic and pre-Mesozoic rocks (Sanz et al. 2012). Available ${ }^{87} \mathrm{Sr} /{ }^{86} \mathrm{Sr}$ values provide an ${ }^{87} \mathrm{Sr} /{ }^{86} \mathrm{Sr}$ range of $0.70710-0.70798$ for the former, and 0.70744-0.70819 for the latter $(\mathrm{n}=25)$ (Nieto et al. 2005; Ortí et al. 2014). The local ${ }^{87} \mathrm{Sr} /{ }^{86} \mathrm{Sr}$ range obtained for the prehistoric human population interred at Marroquíes (0.70675-0.71019) is thus consistent with these environmental results, while the slightly higher values probably relate to Marroquíes' location in an ecotone between the Baetic System and the Neogene and Quaternary formations immediately north of the site. When compared to other ${ }^{87} \mathrm{Sr} /{ }^{86} \mathrm{Sr}$ ranges $(1 \sigma)$ from third- and second-millennium BC archaeological sites and geological samples in Iberia, Marroquíes shows low values-similar to 

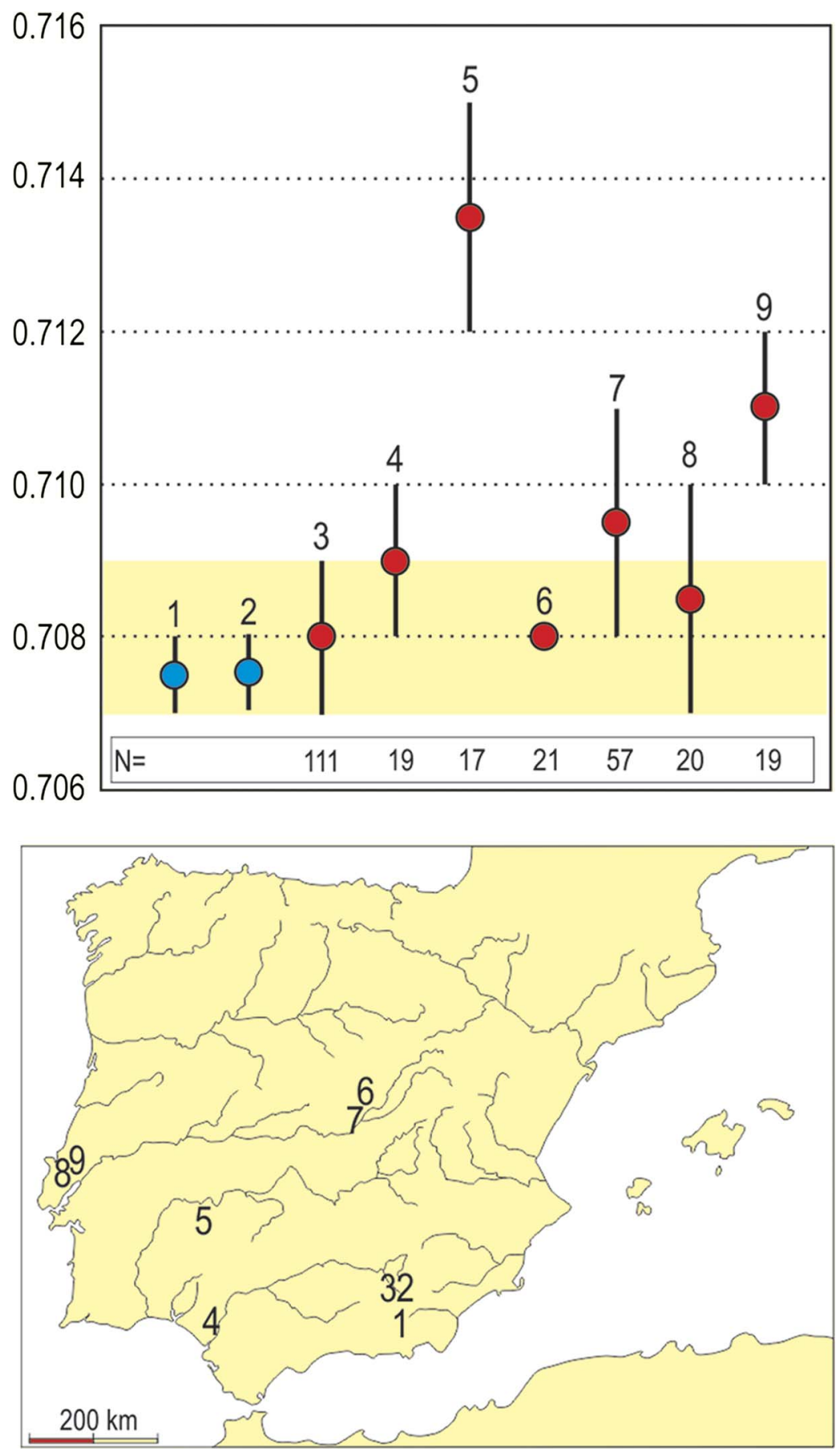

Figure 7. Above: mean averages (filled circles) and $1 \sigma$ range for ${ }^{87} \mathrm{Sr}{ }^{86} \mathrm{Sr}$ values: 1) Baetic System external; 2) Baetic System internal; 3) Marroquies; 4) Valencina; 5) La Pijotilla; 6) El Rebollosillo (Madrid); 7) Madrid Basin; 8) Zambujal; 9) Bolores. Sample sizes are shown in the white box at the bottom of the plot. Geological samples are shown in blue, archaeological samples are shown in red. Below: location of referenced sites.

(C) Antiquity Publications Ltd, 2018 
Cretaceous areas, such as the contemporaneous central Iberian burial cave of El Rebollosillo (average ${ }^{87} \mathrm{Sr} /{ }^{86} \mathrm{Sr}$ of 0.708) (Díaz-del-Río et al. 2017a). It is also lower than most other sampled archaeological sites, including the mega-site of Valencina-Castilleja $\left({ }^{87} \mathrm{Sr} /{ }^{86} \mathrm{Sr}\right.$ values range from 0.708-0.710) (Díaz-Zorita Bonilla 2017)—Marroquíes' western counterpart in the Lower Guadalquivir Valley, with which its Sr isotopic values partially overlap.

With regard to their spatial distribution, one of the six Sr outliers belongs to N4, and five belong to $\mathrm{N} 1$, representing 1 per cent and 23 per cent of the sampled mortuary populations, respectively. Only two individuals with non-local values are subadults, and both are from N1. Four of these individuals have been radiocarbon dated (Table S1). The distribution of these dates throughout the main use-period of the site suggests that this small influx of nonlocal individuals most probably occurred throughout the history of the aggregation process. Nevertheless, a Bayesian model (at $1 \sigma$ ) of the nine radiocarbon dates from N1 suggests that the burial site was in use for approximately 200 years, starting $2610-2495 \mathrm{cal}$ BC and ending by $2465-2390 \mathrm{cal} \mathrm{BC}$. This coincides with the suggested period of maximum construction activity at Marroquíes (c. 2500-2400 cal BC). That is, the entire mortuary area-including all non-local individuals-temporally overlaps with the period during which the majority of the construction activity was in progress at the settlement. This finding is consistent with the settlement pattern data, which imply that by $2500 \mathrm{cal} \mathrm{BC}$, the number of contemporaneous settlements in the Guadalbullón Valley dropped to the lowest level in the entire late prehistoric sequence due to the aggregation at Marroquíes (Díaz-del-Río 2004). If the detected non-local individuals did not grow up in close proximity to the site (e.g. the Guadalbullón Valley), our Sr isotopic results showed that at the peak of labour investment in enclosure construction, Marroquíes may have incorporated a substantial influx of non-local individuals. Although the chronological spread and sample size must be taken into account when considering the magnitude of this influx, the trends in population movement suggested by our isotopic dataset conform to archaeological evidence for regional population dynamics and radiocarbon dating of local labour investments at the site.

A more detailed approach to the spatial distribution of these non-locals at N1 is revealing. Six mortuary structures encircled CE22 ('Complejo Estructural', a complex of structures stratigraphically related to each other), the central burial of a probable male adult of local origin (Figure 3). Three adult and two sub-adult newcomers were buried without formal distinction in structures CE14 (2), CE13 (2) and CE27 (1). Both CE14 and CE13 included 15 other individuals, and CE27 included seven. This pattern reveals an important aspect of the aggregation process at Marroquíes: the social mechanisms by which newcomers were incorporated and integrated into the pre-existing social network. If mortuary treatment at N1 is part of a general pattern, by $2500 \mathrm{cal} \mathrm{BC}$ the incoming non-local population did not comprise an autonomous social group; instead, newcomers were assigned privileges and obligations through their inclusion in pre-existing constituent social structures, be these lineages or clans.

The $\delta^{18} \mathrm{O}$ results for the sampled human population (Figure 6) show a $\delta^{18} \mathrm{O}_{\mathrm{dw}}$ average of $-9.47 \% \pm \pm 1.43(-10.91$ to -8.04 at $1 \sigma)$. This high standard deviation is only reduced slightly when taking into account those who exhibit local ${ }^{87} \mathrm{Sr} /{ }^{86} \mathrm{Sr}$ together with subadults, presumably of local origin $\left(\delta^{18} \mathrm{O}_{\mathrm{dw}}-10.65 \%\right.$ to $-7.57 \%$ ). Children exhibit the lowest standard deviation $\left(-8.71 \% 0 \pm 1.25 ;\left(\delta^{18} \mathrm{O}_{\mathrm{dw}}-9.96 \%\right.\right.$ o to $\left.\left.-7.46 \% 0\right)\right)$ compared to all the sampled humans, or to each necropolis individually. Thus, there seems to be a correlation

(C) Antiquity Publications Ltd, 2018 
between age and standard deviation, where younger individuals show less variability than adults. Many factors can contribute to variability in oxygen isotope values in individuals from the same region, including seasonality during the enamel formation time, climate change during tooth formation, altitude, the ingestion of different types of water and food preparation (or by individual archaeological projects using different drinking water conversion formulae) (Pellegrini et al. 2016: 2). The high variability observed in our sample may result from a combination of such factors. The inhabitants of Marroquíes would have had access to a wide selection of both local and regional water sources. The site was surrounded by a water-rich environment, including the immediate sierras, Mágina and Cazorla, to the east, local lakes and watercourses cutting through the actual enclosure system (Figure 2), and the lower Guadalquivir River Basin some $20 \mathrm{~km}$ north that receives water from tributary sources originating in the northern Sierra Morena. In fact, when compared to the available prehistoric samples, $\delta^{18} \mathrm{O}$ variability at Marroquíes almost doubles that observed in regions such as Madrid (Díaz-del-Río et al. 2017b), where the main water sources all lie in the Central Iberian System mountain range. Consequently, logistical mobility (Binford 1980) could be behind the observed variability as much as food preparation in an historical period where boiled food may have been the staple. Both conditions would explain the higher $\delta^{18} \mathrm{O}$ values and lower variability of infants $v s$ the adult population at Marroquíes.

Plotting $\delta^{18} \mathrm{O}$ values against the ${ }^{87} \mathrm{Sr} /{ }^{86} \mathrm{Sr}$ isotope ratios provides an opportunity to identify whether newcomers emigrated from the same home region (Figure 6). Five of the six individuals identified as non-local using strontium isotope ratios $(2 \sigma$, or $95.4 \%$ confidence) are also outliers based on their $\delta^{18} \mathrm{O}_{\mathrm{V}-S M O W}$ values. Two of these outliers have similar $\delta^{18} \mathrm{O}$ values, but markedly different strontium isotope ratios, which would suggest different regional origins. Additionally, six individuals have strontium isotope ratios that fall within the local range, but significantly different $\delta^{18} \mathrm{O}$ values, which suggest that they may be consuming different water sources (Figure 6). When comparing the ${ }^{87} \mathrm{Sr} /{ }^{86} \mathrm{Sr}$ and $\delta^{13} \mathrm{C}$ values, some individuals considered non-local based on strontium isotope ratios showed significantly lower values for $\delta^{13} \mathrm{C}$, revealing dietary differences that may be related to different geographic contexts (Figure 8).

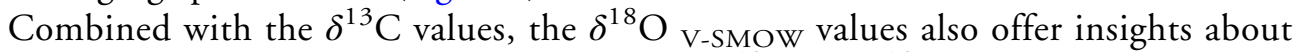
the palaeoecosystem (Figure 9). Lower values for $\delta^{13} \mathrm{C}$ and $\delta^{18} \mathrm{O}$ represent a wetter and denser vegetation. Therefore, those individuals considered non-local based on ${ }^{87} \mathrm{Sr} /{ }^{86} \mathrm{Sr}$ and $\delta^{18} \mathrm{O}$, who spent their childhood in a more radiogenic and higher altitude area, could have come from areas that are relatively close to Marroquíes, such as the Baetic Zone (Figure 6).

To summarise, the results of $\delta^{18} \mathrm{O}$ and ${ }^{87} \mathrm{Sr} /{ }^{86} \mathrm{Sr}$ analyses suggest that at least six of the 115 individuals sampled from the Marroquíes mortuary population can be considered nonlocals. Strontium isotope ratios show 1/78 (1 per cent) non-local individuals at N4-the earliest in the sequence- 5/22 (23 per cent) at N1-contemporaneous with the peak of the aggregation process - and none at $\mathrm{N} 2$, at a time when the site shows signs of depopulation. One child (birth-6.9 years of age), one juvenile (7-12.9 years of age), two young adults (2140 years of age) and two middle adults (41-60 years of age) show non-local strontium isotope ratios. For oxygen, it was only possible to assess sex for three of the non-local adults, and all three estimates were female. Although the sample size is small, the results are consistent with (C) Antiquity Publications Ltd, 2018 


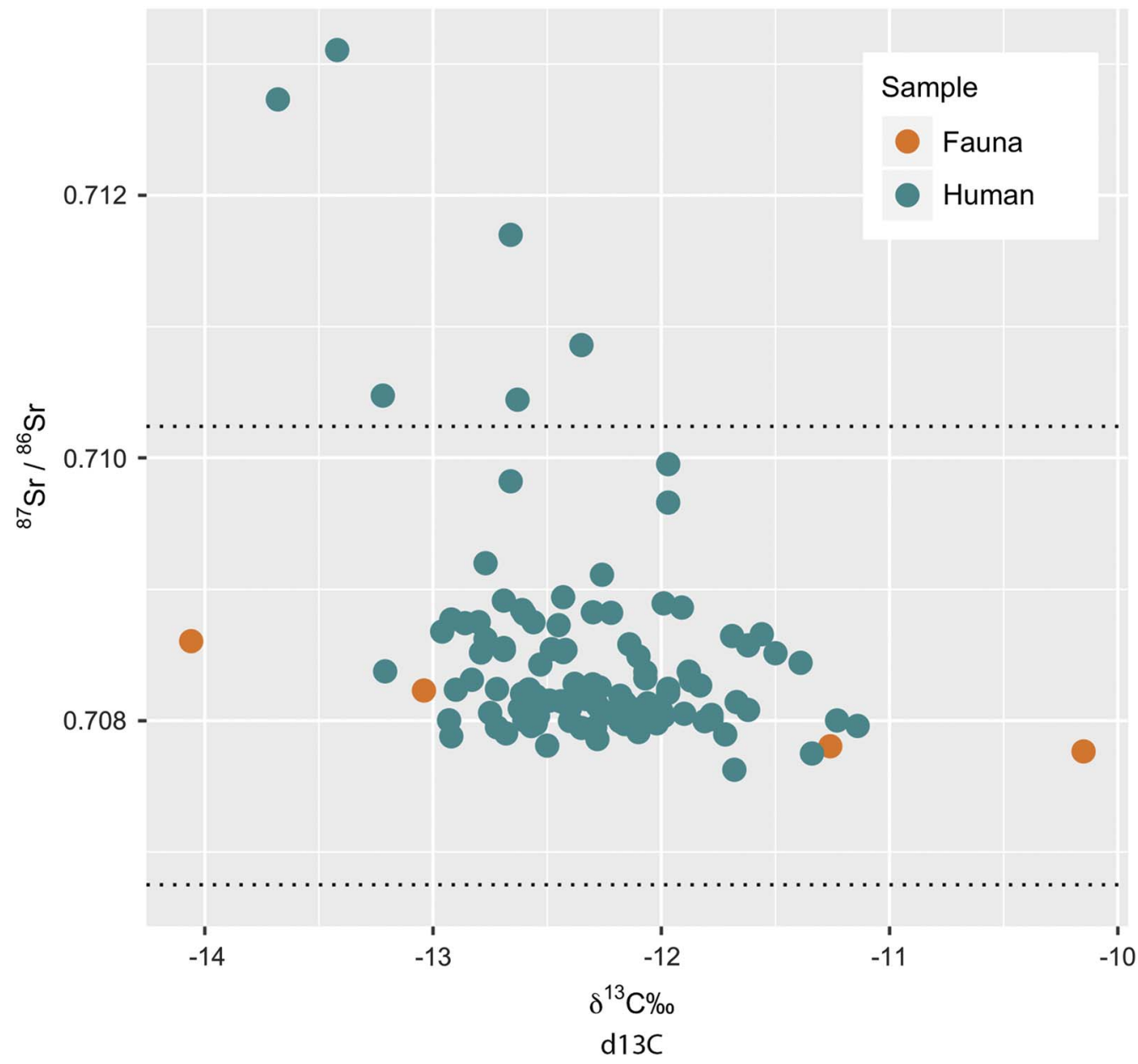

Figure $8{ }^{87} \mathrm{Sr} /{ }^{86} \mathrm{Sr}$ and $\delta^{13} \mathrm{C}$ values for human and faunal samples from Marroquies. Black dotted lines represent $\pm 2 \sigma$ from the human mean for ${ }^{87} \mathrm{Sr}{ }^{86} \mathrm{Sr}$.

research on sex and mobility in central Spain (Díaz-del-Río et al. 2017b) and late prehistoric Europe more broadly, where females are shown to be the more mobile sex (Knipper et al. 2017). The non-local subadults present a particularly intriguing case because at 5-7.5 years of age, these individuals were probably relatively recent additions to the Marroquíes community. Despite growing up outside of the local area, both subadults were given typical mortuary treatment, buried in close proximity to local adults in CE13 and CE14. Regardless of where newcomers originated, it appears that local institutions at Marroquíes were socially inclusive, developing mechanisms that integrated these individuals in both life and death.

\section{Conclusions}

The isotopic evidence presented here suggests that at the peak of mega-site activity in thirdmillennium BC Iberia, Copper Age social institutions developed inclusive mechanisms that 


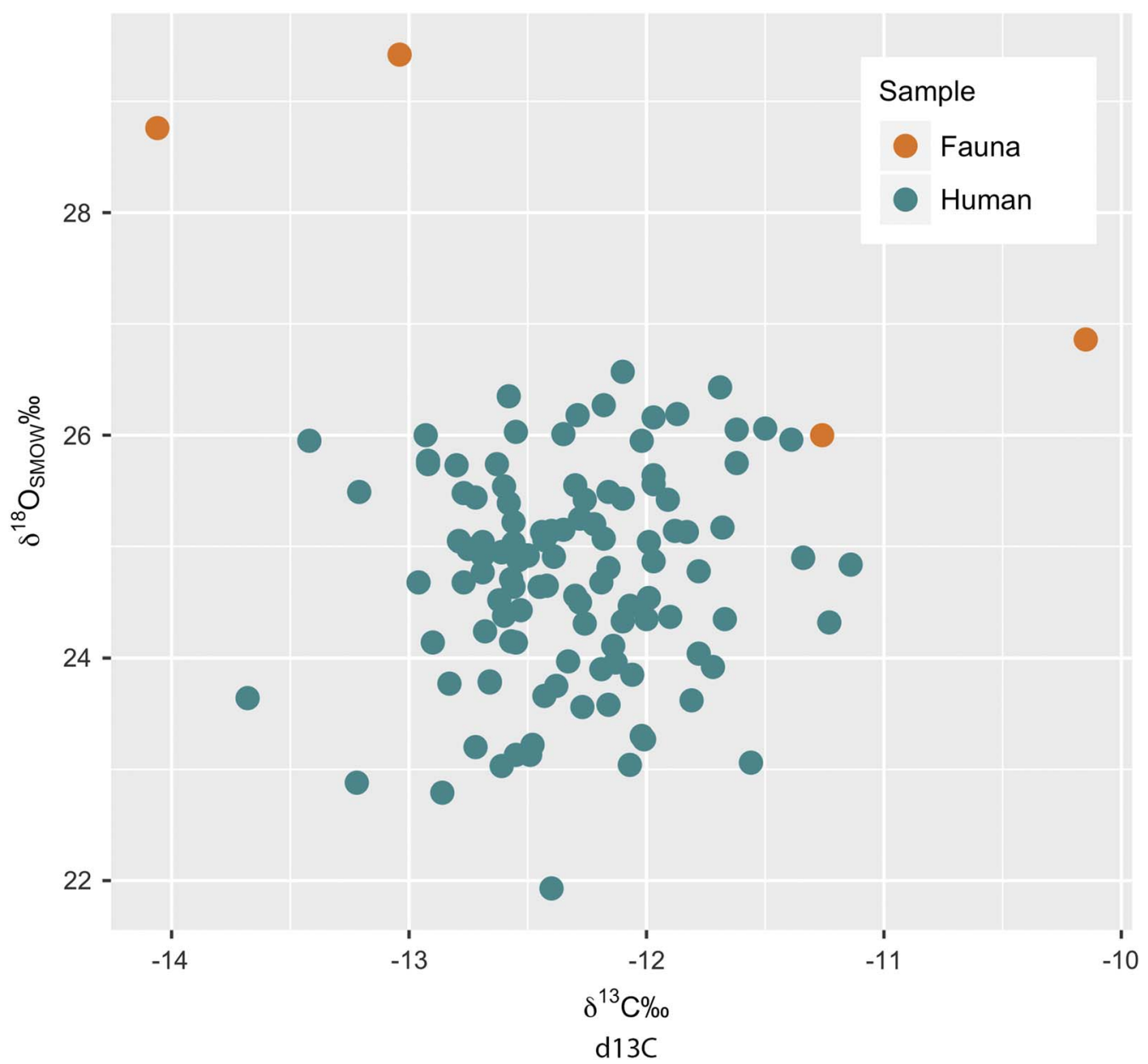

Figure 9. $\delta^{18} O_{V-S M O W}$ and $\delta^{13} C$ values for human and faunal samples from Marroquies.

allowed for the incorporation of both regional and extra-regional immigrants into such communities. Newcomers appear to have been incorporated into the social fabric as full members of the community through pre-existing structuring principles, an inclusion that was overtly sanctioned in death through their incorporation into the local mortuary landscape. The flexibility and inclusiveness of these principles, frequently recognised as a fundamental quality of kinship-based groups, were combined with a resource-rich environment and simple but effective technologies to create conditions that permitted such large-scale aggregation. For several centuries, the social, economic and ideological benefits outweighed the costs of living together. When these ceased-perhaps prompted by prolonged cycles of bad harvests during the $4.2 \mathrm{ka} \mathrm{cal} \mathrm{BP}$ event-the commitment to these norms and institutions disintegrated. This led to the radical reorganisation of the Iberian mega-sites and their constituent populations at the turn of the second millennium BC.

(C) Antiquity Publications Ltd, 2018 


\section{Acknowledgements}

Francisca Hornos (Museo de Jaén) and Narciso Zafra (Delegación Territorial de Cultura, Turismo y Deporte, Jaén) facilitated access to the collections and archival information. Research was made possible by the University of Michigan, Museum of Jaén, the Briggite-Schlieben-Lange programme, the Ministerio de Economía y Competitividad de España (HAR2013-47776-R), the National Science Foundation (BCS-1440017), the SFB 1070 'Ressourcenkulturen' at Tübingen University and Proyectos conjuntos CSIC-Fundación Presidente de Rusia para la Investigación Fundamental (2010RU0086) and a Marie Sklodowska-Curie European Fellowship (746216). Elmar Reitter and Ilka Schoenberg measured the ${ }^{87} \mathrm{Sr} /{ }^{86} \mathrm{Sr}$, and Bernd Steinhilber the $\delta^{13} \mathrm{C}$ and $\delta^{18} \mathrm{O}$ values. Thanks are also due to the two anonymous reviewers whose suggestions contributed to this manuscript.

\section{Supplementary material}

To view supplementary material for this article, please visit https://doi.org/10.15184/aqy.2018.33

\section{References}

Aranda Jiménez, G., A. Lozano Medina, J. Escudero Carrillo, M. Sánchez Romero, E. Alarcón García, S. Fernández Martín, M. Díaz-Zorita Bonilla \& V. Barba Colmenero. 2016. Cronología y temporalidad de los recintos de fosos prehistóricos: el caso de Marroquíes Bajos (Jaén). Trabajos de Prehistoria 73: $231-50$.

https://doi.org/10.3989/tp.2016.12171

Balsera, V., J. Bernabeu, M. Costa-Caramé, P. Díaz-Del-Río, L. García Sanjuán \& S. PARDo. 2015. The radiocarbon chronology of southern Spain's Late Prehistory (5600-1000 cal BC): a comparative review. Oxford Journal of Archaeology 34: 139-56. https://doi.org/10.1111/ojoa.12053

BeCK, J. 2015. Part of the family: age, identity and burial in Copper Age Iberia, in A. Osterholtz (ed.) Theoretical approaches to analysis and interpretation of commingled human remains: 4773. Cham: Springer International.

- 2016. The bioarchaeology of mortuary practice at Marroquíes Bajos, Spain. Unpublished PhD dissertation, University of Michigan.

- 2017. Bioarchaeological approaches to social organization at Marroquíes (Jaén, Spain). Menga. Journal of Andalusian Prehistory 8: 29-50.

BINFORD, L.R. 1980. Willow smoke and dogs' tails: hunter-gatherer systems and archaeological site formation. American Antiquity 45: 4-20.

Birch, J. (ed.). 2013. From prehistoric villages to cities. Settlement aggregation and community transformation. New York: Routledge.
Bowen, G.J. \& J. Revenaugh. 2003. Interpolating the isotopic composition of modern meteoric precipitation. Water Resources Research 39: 1299. https://doi.org/10.1029/2003WR002086

Bowen, G.J., L.I. WassenaAr \& K.A. Hobson. 2005. Global application of stable hydrogen and oxygen isotopes to wildlife forensics. Oecologia 143: 337-48. https://doi.org/10.1007/s00442-004-1813-y

Cámara, J., L. Spanedda, R. Sánchez, M. García, A. GonZÁlez \& J. Nić́s. 2012a. La cronología absoluta de Marroquíes (Jaén) en el contexto de la Prehistoria Reciente del Alto Guadalquivir. ANTIQVITAS 24: 81-94.

Cámara, J., R. SÁnchez, Z. LafFranchi, S. Martín, J. Riquelme, L. Spanedda, M. García, A. González, S. Jímenez \& J. NicÁs. 2012b. La cronología y variedad de los sistemas funerarios en Marroquíes. Una aproximación desde las excavaciones del sistema tranviario de Jaén. SAGVNTVM: Papeles del Laboratorio de Arqueología de Valencia 44: 47-66.

Chenery, C., V. Pashley, A. Lamb, H. Sloane \& J. Evans. 2012. The oxygen isotope relationship between the phosphate and structural carbonate fractions of human bioapatite. Rapid Communications in Mass Spectrometry 26: 309-19. https://doi.org/10.1002/rcm.5331

Daux, V., C. LÉcuyer, M.A. Héran, R. Аmiot, L. Simon, F. Fourel, F. Martineau, N. Lynnerup, H. Reychler \& G. Escarguel. 2008. Oxygen isotope fractionation between human phosphate and water revisited. Journal of Human Evolution 55: 1138-47. https://doi.org/10.1016/j.jhevol.2008.06.006 
Diaz-DEL-Río, P. 2004. Factionalism and collective labor in Copper Age Iberia. Trabajos de Prehistoria 61: 85-98. https://doi.org/10.3989/tp.2004.v61.i2.44 - 2013. Las agregaciones de población del III Milenio AC en la Península Ibérica, in L. Garcia Sanjuán, J.M. Vargas Jiménez, V. Hurtado Pérez, T. Ruiz Moreno \& R. Cruz-Auñón Briones (ed.) El asentamiento prehistórico de Valencina de La Concepción (Sevilla): investigación y tutela en el 150 aniversario del descubrimiento de La Pastora: 65-76. Sevilla: Universidad de Sevilla.

Díaz-del-Río, P., S. Consuegra, J. Audije, S. Zapata, O. Cambra, A. Gonzalez, A. Waterman, J. Thomas, D. Peate, C. Odriozola, R. Villalobos, P. Bueno \& R. Н. Түкот. 2017a. Un enterramiento colectivo en cueva del III milenio AC en el centro de la Península Ibérica: el Rebollosillo (Torrelaguna, Madrid). Trabajos de Prehistoria 74: 68-85.

Díaz-DEL-Río, P., A. Waterman, J. Thomas, D. Peate, R. Tykot, M. Martínez-Navarrete \& J. Vicent. 2017b. Diet change and mobility patterns in the Late Prehistory of central Iberia (4000-1400 cal BC). The evidence of radiogenic $\left({ }^{87} \mathrm{Sr} /{ }^{86} \mathrm{Sr}\right)$ and stable $\left(\delta^{18} \mathrm{O}, \delta^{13} \mathrm{C}\right)$

isotope ratios. Archaeological and Anthropological Sciences 9: 1439-52. https://doi.org/10.3989/tp.2017.12184

Díaz-Zorita Bonilla, M. 2017. The Copper Age in south-west Spain: a bioarchaeological approach to prehistoric social organization (British Archaeological Reports International series S2840). Oxford: Archaeopress.

EspantalÉon, R. 1957. La nécropolis eneolítica de 'Marroquíes Altos'. Boletín Del Instituto de Estudios Giennenses 13: 165-74.

- 1960. La necrópolis en cueva artificial de Marroquies Altos-Cueva III. Boletin Del Instituto de Estudios Giennenses 62: 35-51.

García Sanjuán, L., J.M. Vargas Jiménez, L.M. Cáceres Puro, M.E. Costa Caramé, M. DíazGuardamino Uribe, M. Díaz-Zorita Bonilla, A. Fernández Flores, V. Hurtado Pérez, P.M. López Aldana, E. Méndez Izquierdo, A. Pajuelo Pando, J. Rodríguez Vidal, D. Wheatley, C. Bronk Ramsey, A. Delgado-Huertas, E. Dunbar, A. Mora GonzÁlez, A. Bayliss, N. Beavan, D. Hamilton \& A. Whittle. 2018. Assembling the dead, gathering the living: radiocarbon dating and Bayesian modelling for Copper Age Valencina de la Concepción (Seville, Spain). Journal of World Prehistory 31: 179-313. https://doi.org/10.1007/s10963-018-9114-2

Jarvis, A., H.I. Reuter, A. Nelson \& E. Guevara. 2008. Hole-filled seamless SRTM data V4. International Centre for Tropical Agriculture (CIAT). Available at: http://srtm.csi.cgiar.org (accessed 4 July 2018).

Junta de Andalucía. 2010. Ciudad de la Justicia de Jaén. Excavaciones Arqueológicas. Sevilla: Consejería de Justicia y Administración Pública, Junta de Andalucía.

Knipper, C., A. Mittinik, K. Massy, C. Kociumaka, I. Kucukkalipci, M. Maus, F. Wittenborn, S.E. Metz, A. Staskiewicz, J. Krause \& P.W. Stockhammer. 2017. Female exogamy and gene pool diversification at the transition from the Final Neolithic to the Early Bronze Age in Central Europe. Proceedings of the National Academy of Sciences of the USA 114: 10083-88. https://doi.org/10.1073/pnas.1706355114

LuCAs, M. 1968. Otra cueva artificial en la necrópolis 'Marroquíes Altos' de Jaén (Cueva IV). Excavaciones Arqueológicas en España 62: 3-26.

Manzano, A. \& J. Martínez. 2001. Informe de la Intervención Arqueológica en C/ Cristo Rey N 5 , de Jaén en Cuevas Artificiales de Marroquies Altos (Expediente 56/05). Jaen: Guiomar H.C.M.

Müller, J., K. Rassmann \& M. Videiko. 2016. Tripillia mega-sites and European prehistory 4100-3400 BCE (Themes in Contemporary Archaeology, Volume 2). London: Routledge.

Nieto, L.M., P.A. Ruiz-Ortiz, J. Rey \& M.I. Benito. 2005. Datación de niveles condensados: Precisiones cronoestratigráficas utilizando estratigrafía de isótopos de Sr. Geogaceta 38: 87-90.

Nocete, F. 1994. La formación del estado en las campiñas del Alto Guadalquivir (3000-1500 a.n. e.). Análisis de un proceso de transición. Granada: Universidad de Granada.

Nocete, F., R. Lizcano, A. Peramo \& E. Gómez. 2010. Emergence, collapse and continuity of the first political system in the Guadalquivir Basin from the fourth to the second millennium BC: the long-term sequence of Úbeda (Spain). Journal of Anthropological Archaeology 29: 219-37. https://doi.org/10.1016/j.jaa.2010.03.001

Ortí, F., A. Pérez López, J. García Veigas, L. Rosell, D.I. Cendón \& F. Pérez-Valera.

(C) Antiquity Publications Ltd, 2018 
2014. Sulfate isotope composition $\left(\delta^{34} \mathrm{~S}, \delta^{18} \mathrm{O}\right)$ and strontium isotopic ratios $\left({ }^{87} \mathrm{Sr} /{ }^{86} \mathrm{Sr}\right)$ of Triassic evaporites in the Betic Cordillera (SE Spain). Revista de la Sociedad Geológica de España 27(1): 79-89.

Pellegrini, M., J. Pouncet, M. Jay, M. Parker Pearson \& M.P. Richards. 2016. Tooth enamel oxygen 'isoscapes' show a high degree of human mobility in prehistoric Britain. Scientific Reports 6: 34986.

https://doi.org/10.1038/srep34986

Pérez, M. 2005. Memoria Final de la Intervención Arqueológica Preventiva en Bulevar II Fase. Sector SUNP 1. Jaén: Excmo Ayuntamiento de Jaén.

Porčrć, M. 2012. Effects of residential mobility on the ratio of average house floor area to average household size: implications for demographic reconstructions in archaeology. Cross-Cultural Research 46: 72-86. https://doi.org/10.1177/1069397111423889

Price, T.D., R. Bentley, J. Lüning, D. Gronenborn \& J. Wahl. 2001. Prehistoric human migration in the Linearbandkeramik of Central Europe. Antiquity 75: 593-603. https://doi.org/10.1017/S0003598X00088827

Sánchez, A., J. Bellón \& C. Rueda. 2005. Nuevos datos sobre la zona arqueológica de Marroquíes Bajos: el quinto foso. Trabajos de Prehistoria 62: 151-64. https://doi.org/10.3989/tp.2005.v62.i2.73
Sanz, C., F.J. García-tortosa, J.A. Peláez, P. Alfaro, J.M. Azañon, J. Galindo-Zldívar, C. López-Casado, A.C. López-Garrido, J. Rodríguez-Fernándes \& P. Ruano. 2012. Main active faults in the Granada and GuadixBaza Basins (Betic Cordillera). Journal of Iberian Geology 38: 209-23.

Serrano, J., J. Cano, Y. Jimenez \& F. Alcala. 2000. Urbanización SUNP-1 (1a Fase) de Jaén. Intervención Arqueológica de Urgencia Informe de los Tramos Afectados en: Distribuidor Sur, Calle A y Calle 1. Jaén: EPSA.

VAN DER Merwe, N.J. 1982. Carbon isotopes, photosynthesis, and archaeology: different pathways of photosynthesis cause characteristic changes in carbon isotope ratios that make possible the study of prehistoric diets. American Scientist 70: 596-606.

WaterIsotopes Database. 2017. Available at: http://waterisotopes.org (accessed 4 July 2018).

Zafra, N., F. Hornos \& M. Castro. 1999. Una macro-aldea en el origen del modo de vida campesino: Marroquíes Bajos (Jaén) c. 2500-2000 cal. ANE. Trabajos de Prehistoria 56: 77-102. https://doi.org/10.3989/tp.1999.v56.i1.291

Zafra, N., M. Castro \& F. Hornos. 2003. Sucesión y simultaneidad en un gran asentamiento: la cronología de la macro-aldea de Marroquíes Bajos, Jaén. c. 2500-2000 CAL ANE. Trabajos de Prehistoria 60: 79-90.

Received: 29 August 2017; Revised: 10 February 2018; Accepted: 27 February 2018

(C) Antiquity Publications Ltd, 2018 